\title{
Survey of dental diseases in Crioulo breed horses reared in an extensive farming system
}

\author{
[Levantamento de afecções dentárias em equinos da raça Crioula mantidos em sistema de \\ criação extensivo] \\ C.T. Leite $^{1}$, C.A. Duarte ${ }^{2}$, F.D. Mozzaquatro ${ }^{2}$, M.L.A. Mistieri' ${ }^{2}$, I.R.L. Machado ${ }^{2}$, \\ M.L. Porciuncula ${ }^{2}$, I.S. Leoni², G. Döwich ${ }^{2}$, G.C. Góss ${ }^{2}$, \\ A.P. Santini ${ }^{2}$, E.P. Pereira ${ }^{3}$ \\ ${ }^{1}$ Universidade Estadual Paulista - Jaboticabal, SP \\ ${ }^{2}$ Universidade Federal do Pampa - Uruguaiana, RS \\ ${ }^{3}$ Centro Médico de Cavalos - Varginha, MG
}

\begin{abstract}
The present study aimed to identify and quantify dental diseases in Crioulo horses reared exclusively under extensive farming conditions. In total, 254 Crioulo horses were evaluated, that were reared exclusively in native pastures with predominantly Eragrostis plana (Annoni grass). The animals were divided into three groups according to age: three to five years (G1), six to 12 years (G2), and 13 to 26 years (G3). In total, $46.1 \%$ of the animals in G1, $63.8 \%$ in G2, and $82.3 \%$ in G3 had two or more incisor disorders; $37.5 \%$ in G1, $52.5 \%$ in G2 and $45.5 \%$ in G3 had two or more disease findings in the canines; and $28.9 \%$ in G1, 35.4\% in G2, and $64.7 \%$ in G3 had four or more disease findings in the second, third, and fourth premolars and molars. However, dental calculus was observed in 90.5\% of G2 animals, whereas in G3, the occurrence rate of excessive enamel points and calculus was $82.4 \%$. Although all of the horses studied were reared in an extensive farming system, dental changes were very common in the Crioulo breed reared under these management conditions.
\end{abstract}

Keywords: horses and crioulo breed, dental diseases

\section{RESUMO}

O presente estudo teve por objetivo identificar e quantificar as afecções odontológicas de equinos da raça Crioula criados exclusivamente em regime extensivo. No total, foram avaliados 254 cavalos Crioulos, criados em pastagens nativas com predominância de Eragrostis plana (capim-annoni). Os animais foram divididos em três grupos, de acordo com a idade: de três a cinco anos (G1), seis a 12 anos (G2) e 13 a 26 anos (G3). No total, 46,1\% dos animais do G1, 63,8\% do G2 e 82,3\% do G3 apresentaram dois ou mais transtornos incisivos; $37,5 \%$ do G1, 52,5\% do G2 e 45,5\% do G3 tiveram duas ou mais alterações nos caninos; $28,9 \%$ do G1, 35,4\% do G2 e 64,7\% do G3 mostraram quatro ou mais distúrbios no segundo, terceiro e quarto pré-molares e molares. Contudo, cálculo dentário foi observado em $90,5 \%$ dos animais do G2, enquanto no G3, a taxa de ocorrência de pontas excessivas de esmalte dentário e cálculo foi de $82,4 \%$. Concluiu-se que, apesar de todos os equinos estudados serem mantidos em sistema extensivo, as afecções dentárias mostraram-se muito comuns na raça Crioula sob estas condições de manejo.

Palavras-chave: equinos e raça Crioula, afecções odontológicas

\section{INTRODUCTION}

Horses are herbivores with continuous and selective grazing habits. The type of diet is an extremely important extrinsic factor for the

Recebido em 3 de outubro de 2017

Aceito em 17 de maio de 2018

E-mail: carlateixeiraleite@ hotmail.com chewing cycle (Baker, 2002). Management intensification has been responsible for the appearance of dental disorders, as demonstrated by Muñoz et al. (2010), Lima et al. (2011), Jackes et al. (2011), and Amaya et al. (2012), who have studied horses stabled in different regions of the world. In Brazil, studies have been 
conducted on food supplementation and restricted grazing for horses, and the importance of identifying and quantifying diseases in horses reared in extensive farming conditions and their relationship with the breed and age of the horse is emphasized (Lima et al., 2011).

Crioulo horses, for the most part, consume native grasses as the basis of their diet, with or without the addition of artificial pastures or strategic supplementation. This characteristic is very relevant for this breed, which is known for its hardiness and multifunctionality (Vidart, 2004).

The establishment of functionality trails such as the Golden Bridle and economic return on investments for proven genetic strategies has led investors to intensify the management of these athletic animals. Thus, to meet the current market demands for Crioulo horses, it is extremely important that the dental changes in this breed are surveyed. This study aimed to identify and quantify the dental diseases in Crioulo horses reared exclusively in extensive farming systems.

\section{MATERIALS AND METHODS}

The experimental protocol used in the present study was approved by the Animal Ethics Committee (AEC) of the Federal University of Pampa [Universidade Federal do Pampa] (Protocol No. 019/2013).

The population of Crioulo horses in the municipality has been estimated by the Center for Crioulo Horses of Uruguaiana, Rio Grande do Sul (RS) [Núcleo de Cavalos Crioulos de Uruguaiana/RS], to be 30,920 animals. Thus, the minimum number of horses to be included in the experiment was calculated as 163 . For this calculation, a prevalence of dental diseases of $88 \%$ was assumed with an expected misdiagnosis rate of $5.0 \%$, as recommended by Muñoz et al. (2010)

In total, 254 Crioulo breed animals were used that were between 3 and 26 years of age and had not received dental treatments. They were divided into three groups: animals three to five years of age (G1), animals six to 12 years of age (G2), and animals 13 to 26 years of age (G3). All animals were reared in an extensive farming system in the municipality of Uruguaiana, and their diet was based on native grasses, predominantly Eragrostis plana (Annoni grass). For the assessment of the oral cavity, sedation with detomidine hydrochloride (Dormiun V, detomidine hydrochloride, Agener União Saúde Animal, Brazil) at an intravenous dose of $20 \mu \mathrm{g} / \mathrm{kg}$ (Valverde, 2005) was used for animals that could not be physically restrained. The dental evaluation included an inspection and palpation of the bony structures of the face, lips, gums, incisors, and canines. For the evaluation of the oral cavity, dental halter and mouth speculum were used in all horses for further cleaning and examination of the premolars, molars, oral mucosa, tongue, and palate. The results were analyzed using the chi-square test with a $95 \%$ confidence level.

\section{RESULTS AND DISCUSSION}

In the present study, although the number of animals needed was determined to be 163 , a total of 254 horses were evaluated, which is significantly more than the requirement.

The mouth speculum was carefully placed in all animals of the experiment, which were docile and allowed the proper evaluation of the intraoral cavity and the correct classification of the lesions. As no painful stimuli were caused to perform the examination, sedation was required in only 46 of the horses examined.

The present study found that incisor changes were frequent, such that $46.1 \%$ of the animals in $\mathrm{G} 1,63.8 \%$ in $\mathrm{G} 2$, and $82.3 \%$ in $\mathrm{G} 3$ had at least two diseases in this dental group, contrary Dixon and Dacre (2005), which state that such findings are expected in animals in intensive system. Muñoz et al. (2010) studied confined Chilean horses and reported that $84.0 \%$ had some type of incisor disorder; of these changes, $26.02 \%$ were due to developmental disorders, and $74.0 \%$ were acquired.

In an evaluation of the qualitative changes, $47.1 \%$ of the animals in $\mathrm{G} 1,43.1 \%$ in $\mathrm{G} 2$, and $58.8 \%$ in G3 had irregular alignments (Table 1). This finding suggests that the occurrence of occlusal disorders of the incisors in the animals studied resulted primarily from the fibrous characteristics of the forage. 
Table 1. Frequency of dental changes in Crioulo horses reared in an extensive farming system, according to dental group (incisors [I]; canines [C]; premolars [PM]; molars [M]) and by age category G1; G2; G3)

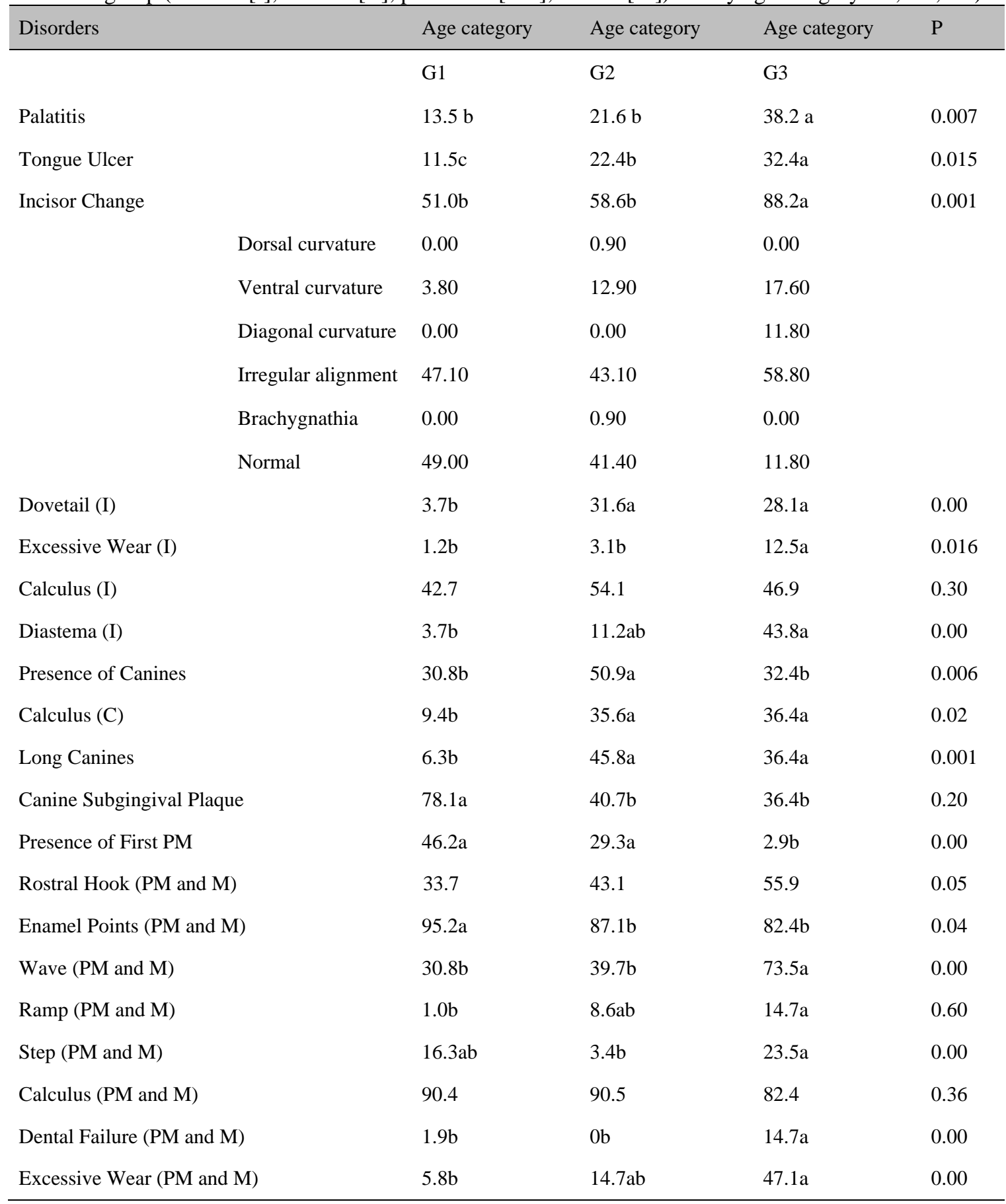

* Statistically significant using the chi-square test with a $95 \%$ significance level.

In addition, the incisor changes in the animals in G1 included dental calculus, which was observed in $42.7 \%$ of the animals (Table 1), $37.8 \%$ of which also had gingivitis. These observations seem to contradict Klugh (2005), as they are not expected in animals reared in an extensive farming system but in animals with restricted access to pasture and a diet based on hay and grain. Thus, the occurrence of calculus may be related to breed predisposition which would 
require additional studies to confirm. This finding is important because calculus can be a precursor to gingivitis, which is observed in many horses with calculus, and periodontal disease (Johnson and Porter, 2006). Dovetail was observed in $3.7 \%$ of the animals in $\mathrm{G} 1,31.6 \%$ in $\mathrm{G} 2$, and $21.8 \%$ in $\mathrm{G} 3(\mathrm{P}=0.000)$, whereas $3.7 \%$ of the animals in $\mathrm{G} 1,11.2 \%$ in $\mathrm{G} 2$, and $43.8 \%$ in $\mathrm{G} 3$ had diastema ( $\mathrm{P}=0.000)$, and another $3.7 \%$ in $\mathrm{G} 1,2.0 \%$ in $\mathrm{G} 2$, and $3.1 \%$ in $\mathrm{G} 3$ had retained deciduous incisors (Table 1). Diastema may be associated with the retention of deciduous incisors (Dixon and Dacre, 2005).

In $\mathrm{G} 2$, the most commonly encountered condition in incisors teeth was calculus $(42.7 \%)$, followed by dovetail (31.6\%) and idiopathic enamel fractures without pulp exposure (30.6\%). The most frequent dental fractures were relatively small, estimated at $\leq 5 \mathrm{~mm}$ (Table 1). According to Muñoz et al. (2010), the most commonly encountered condition associated with the incisors of stabled Chilean horses was fractures, which was observed in $46.0 \%$ of the study population, followed by calculus in $33.0 \%$. In the present study, the low prevalence of fractures may be the result of the extensive management provided for the animals. Gingivitis was observed in $37.8 \%$ of the animals in G1, $26.5 \%$ in $\mathrm{G} 2$, and $28.1 \%$ in $\mathrm{G} 3$, which was possibly caused by eruption in G1 and G2 and by dental calculus in G3. The primary reason for the occurrence of excessive wear of incisors in $12.5 \%$ of $\mathrm{G} 3$ animals is thought to be related to diet (Table 1).

As for congenital abnormalities, parrot mouth occurred in $0.9 \%$ of the animals in G2. This result is consistent with Jacques et al. (2011), who found no brachygnathia in 142 Crioulo horses. However, Amaya et al. (2012) reported higher values, which approached $7.0 \%$ in Colombian Crioulo horses. The occurrence of prognathism was not observed in this study.

In the study population, $37.5 \%$ of the animals in $\mathrm{G} 1,52,5 \%$ in $\mathrm{G} 2$ and $45,5 \%$ in G3 had at least two findings in their canines. Elongated canines were observed in $6.3 \%$ of the horses in $\mathrm{G} 1$, in $45.8 \%$ in $\mathrm{G} 2$ and in $36.4 \%$ in G3. Excessive growth of the canines occurs due to the absence of occlusion of these teeth (Linkous, 2006).
In $\mathrm{G} 1,78.1 \%$ of the animals had canine subgingival plaque $(\mathrm{P}=0.000)$ and $3.1 \%$ of this same group had gingivitis. However, $40.7 \%$ of animals in $\mathrm{G} 2$ and $36.4 \%$ in $\mathrm{G} 3$ exhibited canine subgingival plaque and showed no signs of gingivitis. In $\mathrm{G} 1,9.4 \%$ of animals had calculus, whereas this value was $35.6 \%$ in $\mathrm{G} 2$ and $36.4 \%$ in G3 (Table 1). This condition is commonly found in this dental group and may be associated with gingivitis but rarely causes tooth loss (Klugh, 2005; Linkous, 2006). For the animals in $\mathrm{G} 2,1.7 \%$ had fractures, an incidence higher than that reported by Caldwell (2006).

Wolf teeth were present in $46.2 \%$ of the animals in $\mathrm{G} 1$ and $29.3 \%$ in $\mathrm{G} 2$, whereas in $\mathrm{G} 3$, the rate was only $2.9 \%(\mathrm{P}=0.000)$, which was expected based on the percentage reported by Scrutchfield (2002). The main reason that may explain the low incidence of wolf tooth in G2 and G3 animals is the spontaneous loss of these teeth during the eruption of the second premolar (Engelke and Gasse, 2003).

In total, $28.9 \%$ of the animals in $\mathrm{G} 1,35.4 \%$ in $\mathrm{G} 2$, and $64.7 \%$ in $\mathrm{G} 3$ had four or more conditions in their pre-molars and molars, which is consistent with the results reported by Rucker (2006) and Easley (2011), who noted that disorders are closely related and occur concurrently.

The condition that occurred most frequently in the second, third, and fourth premolars and molars was excessive enamel points (Table 1), which was present in $95.2 \%$ of the animals in G1. In contrast, Amaya et al. (2012) reported excessive enamel points in $58.0 \%$ of Colombian Crioulo horses, a much smaller percentage than observed in this study. Baker (2002) and Brigham and Ducanson (2000) reported that this change in horses under nine years of age has an incidence between $44.0 \%$ and $72.0 \%$ and is related to the rhizogenesis of the permanent teeth, which may also be a related factor in this study.

The growth of enamel points can cause unilateral chewing due to pain and abnormal wear patterns of the incisors (Dixon and Dacre, 2005), which was observed and previously noted in this study.

Lima et al. (2011) stated that providing grain at the expense of long fibers, in addition to 
supplying food at above-ground levels, leads to the formation of rostral and caudal hooks. However, in this study, rostral hooks were observed in $33.7 \%$ of the animals in G1, $43.1 \%$ in $\mathrm{G} 2$, and $55.9 \%$ in $\mathrm{G} 3$, which are considerable percentages in animals fed a grass-based diet and were significantly different among the groups $(\mathrm{P}$ $=0.059$ ). The reason for the high incidence of this finding may be the prevalence of steps and waves observed in this study. Linkous (2006) noted that rostral and caudal hooks can occur in young animals between two and five years of age due to the timing of tooth eruption of the premolars and molars.

We observed that $30.8 \%$ of the animals in G1, $39.7 \%$ in $\mathrm{G} 2$, and $73.5 \%$ in G3 (Table 1) had waves $(\mathrm{P}=0.000)$. The formation of waves in young animals is thought to be the result of dental changes and the eruption of premolars and molars, in addition to the highly fibrous characteristics of Annoni grass, which can cause excessive abrasions and uneven wear. Consistent with Scrutchfield and Johnson (2006), the prevalence was highest in G3 animals compared to the other groups.

According to Townsend et al. (2008), steps can be caused by tooth loss, fractures, or defective eruptions. Steps were diagnosed in $16.3 \%$ of the horses in $\mathrm{G} 1,3.4 \%$ in $\mathrm{G} 2$, and $23.5 \%$ in $\mathrm{G} 3(\mathrm{P}=$ 0.000 ) (Table 1); however, $1.9 \%$ of the animals in $\mathrm{G} 1,0.0 \%$ in $\mathrm{G} 2$, and $14.7 \%$ in $\mathrm{G} 3$ had dental failure, which might be responsible for the emergence of steps in some of the horses. Fractures and tooth loss are due to accidents or diseases, and their occurrence can vary. The faulty eruption of teeth is relatively rare (Velázquez, 2009).

Kreling (2003) observed ramps in $1.0 \%$ of animals $\leq 5$ years of age and a significant increase to $10.0 \%$ in horses $>5$ years $(\mathrm{P}=0.002)$. Ramps are triggered by excessive tooth wear, forming terminal projections that can cause soft tissue damage during chewing. It is believed that the type of forage may have caused the ramps in the animals studied.

It was noted in this study that $5.8 \%$ of the animals in $\mathrm{G} 1,14.7 \%$ in $\mathrm{G} 2$, and $47.1 \%$ in $\mathrm{G} 3$ had excessive wear of the premolars and molars
$(\mathrm{P}=0.000)$ (Table 1), which contradicts Easley (2005), who observed abnormal wear of the teeth only in animals with limited access to long fibers. Rucker (2006) noted that the formation of wear disorders affects mature animals, consistent with the findings of the present study.

In $\mathrm{G} 1,5.8 \%$ of the animals had dental fractures in incisors, whereas in premolars and molars the percentages of animals in G2 and G3 were 4.3\% and $2.9 \%$, respectively (Table 1 ). In G1, as also described by Velázquez (2009), this change may be due to competition for food in the paddock, or curiosity, which is a common characteristic among foals. In G2 and G3 fractures are deemed idiopathic (Dacre, 2006). The most common fractures in these cases occur along a vertical plane, often reaching the pulp chamber (Dixon $e t$ al., 2006).

In total, $20.2 \%$ of the animals in G1 had excessive transverse ridges, whereas the incidence was $24.1 \%$ in $\mathrm{G} 2$ and $11.8 \%$ in G3 (Table 1). This may be due to the fibrous characteristics of Annoni grass.

Authors such as Arenas (2003), Dixon and Dacre (2005), and Dacre (2006) have noted that diet supplementation based on grain and pellets is responsible for the high incidence of dental diseases in horses. However, the present study found that changes, especially excessive enamel points, dental calculus, and rostral hooks and waves, were very common in Crioulo horses that feed exclusively on forage.

\section{CONCLUSION}

Less than half of the animals studied had two or more dental disorders in their incisor teeth. For the canine teeth, one or more findings were observed in a large proportion of the horses studied. More than one third of the horses evaluated had four or more findings in their premolars and molars. The conditions with higher incidence included irregular alignment, excessive enamel points, dental calculus, and rostral hooks and waves. Although all of the Crioulo horses studied were reared in an extensive farming system, the dental changes observed are very common in this breed under these management conditions. 


\section{REFERENCES}

AMAYA, J.M.C.; SÁNCHEZ, J.A.; HERNÁNDEZ, L.G.V. Caracterización y prevalencia de las enfermidades orales en el caballo criollo, departamento de caldas, Colombia. Rev. Med. Vet., v.23, p.39-50, 2012.

ARENAS, B. Estudio de prevalência da las principales alteraciones dentales de equinos em piezas de matadero. 2003. Memoria de titulo. Escuela de Medicina Veterinaria, Universidad Santo Thomás, Santiago, CL.

BAKER, G.J. Anomalias del desgaste y enfermedad periodontal In.: BACKER, G.J.; EASLEY, K.J. Odontologia equina. 2.ed. Buenos Aires: Intermédica, 2002. p.79-98.

BRIGHAM, E.J.; DUCANSON, G.R. An equine postmortem dental study: 50 cases. Equine Vet. Educ., v.12, p.59-62, 2000.

CALDWELL, L.A. A review of diagnosis, treatment and sequelae of incisor luxation fractures in horses (from a dentist's standpoint). In: ANNUAL CONVENTION OF THE AMERICAN ASSOCIATION OF EQUINE PRACTITIONERS, 52., 2006, Indianapolis. Proceedings... Indianapolis: [AAEP], 2006. p.559-564. (Resumo).

DACRE, I. Examination for pulp exposure at the occlusal surface and classification of dental fractures. In: ANNUAL CONVENTION OF THE AMERICAN ASSOCIATION OF EQUINE PRACTITIONERS, 52., 2006, Indianapolis. Proceedings... Indianapolis: [AAEP], 2006. (Resumo).

DIXON, P.M. et al. Idiopathic cheek teeth fractures, including practice-based and hospitalbased surveys. In: ANNUAL CONVENTION OF THE AMERICAN ASSOCIATION OF EQUINE PRACTITIONERS, 52., 2006, Indianapolis. Proceedings... Indianapolis: [AAEP], 2006. (Resumo).

DIXON, P.M.; DACRE, I. A review of equine dental disorders. Vet. J., v.196, p.165-187, 2005.

EASLEY, J. Oral and dental examination. In.: AMERICAN ASSOCIATION OF EQUINE PRACTIONERS - FOCUS MEETING, 1., 2011, Albuquerque. Proceedings... Albuquerque: [AAEP], 2011. p.1-8, (Resumo).
EASLEY, K.J. Dental and oral examination. In.: BACKER, G.J.; EASLEY, K.J. Equine dentistry. 2.ed. London: Saunders, 2005. p.151-169.

ENGELKE, E.; GASSE, F. Um estudo anatômico da parte rostral da cavidade oral dos equídeos, com relação à posição e tamanho de um bridão bit. Vet. Equine Educ., v.15, p.158163, 2003.

JACQUES, R.E.; GARCIA, C.A.; DE SOUZA, J.R.M. et al. Alterações odontológicas presentes em equinos da raça Crioula e o efeito da idade na presença destas irregularidades dentárias. In.: ENCONTRO DE PÓS-GRADUAÇÃO DA UFPEL. 15., 2011. Pelotas. Anais... Pelotas: [UFP], 2011. p.1-4. (Resumo).

JOHNSON, T.; PORTER, C. Dental overgrowths and acquired displacement of cheek teeth. In: ANNUAL CONVENTION OF THE AMERICAN ASSOCIATION OF EQUINE PRACTITIONERS, 52., 2006, Indianapolis. Proceedings... Indianapolis: [AAEP], 2006. (Resumo).

KLUGH, D. A review of equine periodontal disease. Clin. Tech. Equine Pract., v.4, p.135147, 2005.

KRELING, K. Horses'teeth and their problems: prevention, recognition and treatment. 2.ed. Luneburg, Germany: Cadmos, 2003.

LIMA, J.T.M.; ANDRADE, B.S.C.; SCHWARZBACH, S.V. et al. Ocorrência de doença infundibular, sobremordida e ganchos em equinos de cavalaria militar. Arq. Bras. Med. Vet. Zootec., v,63, p.6-11, 2011.

LINKOUS, M. Dental conditions affecting the juvenile performance horse (2-5 years). In: ANNUAL CONVENTION OF THE AMERICAN ASSOCIATION OF EQUINE PRACTITIONERS, 52., 2006, Indianapolis. Proceedings... Indianapolis: [AAEP], 2006. (Resumo).

MUÑOZ, L.; VIDAL, F.; SEPÚLVEDA, O. et al. Patologías dentales en incisivos, caninos y primer premolar en caballos chilenos adultos. Arch. Med. Vet., v.42, p.85-90, 2010. 
RUCKER, B. Dental conditions affecting the geriatric horse. In.: ANNUAL CONVENTION OF THE AMERICAN ASSOCIATION OF EQUINE PRACTITIONERS, 52., 2006, Indianapolis. Proceedings... Indianapolis: [AAEP], 2006. (Resumo).

SCRUTCHFIELD, W.L. Pophylaxis dental. In.: BACKER, G.J.; EASLEY, K.J. Odontologia equina. 2.ed. Buenos Aires: Intermédica, 2002. p.205-228.

SCRUTCHFIELD， W.L.; JOHNSON， T.J. Corrective procedures for cheek teeth. In.: PROCEEDINGS OF NORTH AMERICAN VETERINARY CONFERENCE, 20., 2006, Orlando. Proceedings... Orlando: North American Veterinary Conference, 2006. (Resumo).

TOWNSEND N.; DIXON P.M.; BARAKZAI S. Evaluation of the long term consequences of equine exodontia in 50 horses. Vet. J., v.176, p.419-424, 2008.
VALVERDE, A. Sedation for standing procedures. In.: NORTH AMERICAN VETERINARY CONFERENCE, 2005, Florida. Proceedings... Florida: North American Veterinary Conference, 2005. (Resumo).

VELÁZQUEZ, J.L. Equine dentistry. In.: INTERNATIONAL CONGRESS OF WORLD EQUINE VETERINARY ASSOCIATION, 11., 2009, Guarujá. Proceedings... Guarujá: [WEVA], 2009. (Resumo).

VIDART, D. Orígenes del caballo Crioulo. In.: PONCE DE LEÓN, L.; SAN MARTÍN, Z.A. Criollos de America - origen y evolución de una raza legendaria. Montevideo, Uruguay: [s.n.], 2004. p.15-23. 